\title{
The Biologic Implications of a Rare Hemoglobin Mutant That Decreases Oxygen Affinity
}

\author{
HARRY BARD, KRISHNA G. PERI, AND CARMEN GAGNON \\ Department of Pediatrics, University of Montreal, Service of Neonatology and Research Center, Hospital \\ Sainte-Justine, Montreal, Quebec, Canada H3T 1C5
}

\begin{tabular}{|c|c|}
\hline \multicolumn{2}{|c|}{ ABSTRACT } \\
\hline $\begin{array}{l}\text { Blood from seven newborns, a } 13 \text {-y-old, and seven adult } \\
\text { family members with a suspected hemoglobinopathy because of } \\
\text { unexplained cyanosis was obtained for analysis to determine } \mathrm{Hb} \\
\text { oxygen affinity and to characterize and quantify the } \mathrm{Hb} \text { variants. } \\
\text { Their oxygen saturation was } 76 \text { to } 84 \% \text {. The } \mathrm{P}_{50} \text { was } 30.3 \pm 2.9 \\
\text { for the newborns and } 32.5 \pm 2.6 \mathrm{~mm} \mathrm{Hg} \text { for their related adults. } \\
\text { In the same order, the plasma erythropoietin was } 7.4 \pm 2.9 \text { and } \\
15.9 \pm 3.7 \mathrm{mU} / \mathrm{mL} \text {, whereas } 2,3 \text {-diphosphoglycerate was } 16.1 \text {. } \\
\pm 2.9 \text { and } 15.9 \pm 3.7 \mu \mathrm{mol} / \mathrm{g} \mathrm{Hb} \text {. In four of the newborns with } \\
\text { increased } \mathrm{P}_{50} \text {, the mother had a normal } \mathrm{P}_{50}(27 \mathrm{~mm} \mathrm{Hg}) \text {, which } \\
\text { indicated a greater maternal oxygen affinity than the fetus with no } \\
\text { adverse effects on the fetus. Genetic analysis of } \alpha \text {-globin genes } \\
\text { demonstrated a heterozygous mutation on the } \alpha 2 \text { gene } \\
\text { [ } \alpha 94(\mathrm{G} 1) \text { Asp } \rightarrow \text { His] for each of the newborns and their related } \\
\text { adults. The same mutation was found on the } \alpha 1 \text { gene in an } \\
\text { adolescent and her father. The mRNA measurements showed that } \\
\text { the } \alpha 2 \text { - to } \alpha 1 \text {-globin mRNA mean ratio was } 2.5 \text {, } \alpha 2 \text { mutant }\end{array}$ & $\begin{array}{l}\text { globin mRNA/total } \alpha 2 \text {-globin mRNA was } 45.0 \% \text {, whereas the } \\
\alpha 1 \text { mutant globin mRNA/total } \alpha 1 \text {-globin mRNA was } 37.8 \% \text {. The } \\
\text { level of } \alpha 2 \text { mutant globin/total } \alpha \text {-globin was } 27.3 \pm 1 \% \text {, and } \alpha 1 \\
\text { mutant globin/total } \alpha \text {-globin was } 23.8 \pm 1 \% \text {. The percentage of } \\
\text { synthesized } \alpha 2 \text { and } \alpha 1 \text { mutant globins was } 27.5 \pm 2 \text { and } 26.1 \pm \\
1 \text {, respectively. The ratio of the } \alpha 2 / \alpha 1 \text { mutant globins was } 1.1 \text {, } \\
\text { which corresponded to a ratio at the mRNA level of } \alpha 2 / \alpha 1 \text { of } 2.5 \\
\pm 0.5 \text {, which suggested that there is a less efficient translation of } \\
\text { the } \alpha 2 \text { mRNA than } \alpha 1 \text { mRNA. The reversal of the physiologic } \\
\text { fetomaternal oxygen affinity had no effects on fetal development. } \\
\text { (Pediatr Res 49: 69-73, 2001) } \\
\text { Abbreviations } \\
\text { ODC, Hb-oxygen dissociation curve } \\
\text { DPG, 2,3-diphosphoglycerate } \\
\mathbf{P}_{\mathbf{5 0}}, \mathrm{PO}_{2} \text { required to achieve a saturation of } 50 \% \text { at pH } 7.4 \text { and } \\
37^{\circ} \mathrm{C}\end{array}$ \\
\hline
\end{tabular}

A rare mutant $\mathrm{Hb}$ with a low oxygen affinity designated as Sunshine Seth $\left[\alpha 94\left(\mathrm{G}_{1}\right)\right.$ Asp $\rightarrow$ His] (1) was detected in a series of newborn infants as well as in a 13-y-old and her father. The infants, because of persistent cyanosis, were transferred soon after birth to a neonatal intensive care unit to investigate the cause of their $\mathrm{Hb}$ desaturation. The cyanotic infants and their parents provided an opportunity to evaluate the physiologic implications of low oxygen $\mathrm{Hb}$ affinity during the perinatal period as well as carry out genetic analysis to further the knowledge of the of human $\alpha$-globin gene expression.

The two human $\alpha$-globin genes $\alpha 1$ and $\alpha 2$ are coexpressed in normal erythroid cells and encode identical $\alpha$-globin protein products. The $\alpha 2$ gene encodes a 2-3-fold higher level of mRNA than the $\alpha 1$ gene (2). Because of the identical $\alpha$-globin produced, the relative levels of expression are difficult to determine. Despite some data that suggest posttranscriptional/ translational modifications balancing the amount of protein expressed from these mRNA (3), it is still controversial how

Received April 20, 2000; accepted August 28, 2000

Correspondence: Harry Bard, M.D., Research Center, Hospital Sainte-Justine, 3175 Chemin de la Côte Sainte-Catherine, Montreal, Quebec, Canada H3T 1C5.

Supported by Grant \#MT-11552 from the Medical Research Council of Canada. the difference in $\alpha 2$ and $\alpha 1$ mRNA levels are reflected at the protein level (4). Because of a rare occasion in which an identical mutation in both the $\alpha 1$ and $\alpha 2$ genes existed in different individuals, the relative rate of mutant protein production from each of the loci can be determined and compared. These values can be used to evaluate the efficiency of the translation of the $\alpha 1$ and $\alpha 2$ mRNA and to determine the relative contribution of normal $\alpha 1$ and $\alpha 2$ to the total $\alpha$-globin production.

Blood samples obtained from patients with an $\mathrm{Hb}$ oxygen desaturation with a suspected hemoglobinopathy were used to determine their ODC and to measure the effects of $\mathrm{Hb}$ desaturation on DPG and erythropoietin levels. The samples were also used to determine their mutant globin chain identification and its quantification and rate of synthesis. Finally, a series of molecular genetic studies such as a selective amplification of $\alpha 1$ - and $\alpha 2$-globin genes for sequencing and/or digestion with specific restriction enzymes were carried out to determine the mutation locations, RNase protection assay to determine the relative amounts of $\alpha 2$ - and $\alpha 1$-globin mRNA, and reverse transcriptase-PCR (RT-PCR)-ApaL I digestion to quantify the relative amounts of $\alpha 2$ or $\alpha 1$ mutant globin mRNA. 


\section{METHODS}

During a 5-y period (1994-1999), seven newborns from the same region of the province of Quebec were transferred to the neonatal intensive care unit soon after birth because of persistent cyanosis. The infants were born at term with a mean birth weight of $3350 \pm 440 \mathrm{~g}$. They were all appropriate for weight for gestational age. Because of unexplained desaturation and the lack of symptoms, a hemoglobinopathy was suspected. Six parents of these infants and one grandparent with cyanosis were also investigated. More recently, a 13-y-old girl and her father were added to this series because of unexplained cyanosis and desaturation detected in a pediatric clinic. The arterial oxygen saturation by pulse oximetry (Ohmeda oximeter) of these infants and their related adults ranged from 76 to $84 \%$.

Blood samples were obtained to determine the $\mathrm{P}_{50}$ from ODC by use of an ODC Hemox-Analyzer (5). Total globin chain content and the rate of protein synthesis was determined by labeling immature red cells with ${ }^{3} \mathrm{H}$-leucine and separation of the globins by HPLC (6); as plasma erythropoietin and red cell DPG concentrations were determined by RIA (7) and an enzymatic method, respectively (8). Finally, DNA and mRNA analysis was carried out on the samples as described below.

$\boldsymbol{O D C}$. ODC were obtained using the Hemox-Analyzer (TCS Scientific Corp., New Hope, PA, U.S.A.). Fifty microliters of whole blood was added to $4 \mathrm{~mL}$ of buffer ( $135 \mathrm{mM} \mathrm{NaCl}, 30$ $\mathrm{mM}$ TES, $5 \mathrm{mM} \mathrm{KCl}$, and $\mathrm{NaOH}$ adjusted to $\mathrm{pH} 7.4 \pm 0.02$ ) (TCS buffer; TCS Scientific Corp.), $10 \mu \mathrm{L}$ of antifoam solution, and $20 \mu \mathrm{L}$ of $20 \%$ BSA. Samples were analyzed immediately upon collection from the patient. Nitrogen $(100 \%)$ was bubbled through the sample at a constant rate that resulted in complete deoxygenation within $20 \mathrm{~min}$, followed by reoxygenation with air for $15 \mathrm{~min}$. The analyzer measured the oxygen tension with a standard Clark $\mathrm{O}_{2}$ electrode (model 5331 Oxygen Probe; Yellow Springs Instrument Co., Yellow Springs, $\mathrm{OH}$, U.S.A.) and simultaneously calculated the $\mathrm{Hb}$ saturation by use of dual-wavelength spectrophotometry. The ODC were recorded during both deoxygenation and reoxygenation. The membrane was deoxygenated and reoxygenated in distilled water for a 12 -h period the day before all patient studies. The night before each study day, a sample of fresh adult blood was run as a standardization control.

DNA analysis. Genomic DNA was isolated using a QIA amp kit (Qiagen) from the blood samples of patients who had an $\alpha$-globin variant detected by HPLC. The genomic DNA $(0.5$ $\mu \mathrm{g})$ was subjected to selective amplification of $\alpha 1$ and $\alpha 2$ DNA using primers in which the upstream primer is common for both $\alpha$ genes- 5'CCACCAAGATCTACTTCCCGC3' (located in Fig. 1). The $\alpha 1$-specific downstream primer5'TCAAAGACCACGGGGGTACG3' (located in Fig. 1) and the $\alpha 2$-specific downstream primer-5'CTTTATTCAAAGACCAGGAAGGG3' (located in Figs. 1 and 2) amplified specific fragments of $550 \mathrm{bp}$ each. The reaction mixture $(50 \mu \mathrm{L})$ contained 1X PCR buffer (GIBCO), 25 pmol of primer, 0.2 $\mathrm{mM}$ dNTP, $1.5 \mathrm{mM}$ magnesium chloride, 10\% DMSO, 5\% glycerol, and $1.25 \mathrm{U}$ of $\mathrm{Taq}$ polymerase (GIBCO). An initial denaturation for $3 \mathrm{~min}$ at $94^{\circ} \mathrm{C}$ followed by 25 cycles of $94^{\circ} \mathrm{C}$ for $1 \mathrm{~min}, 52^{\circ} \mathrm{C}$ for $1 \mathrm{~min}, 72^{\circ} \mathrm{C}$ for $1 \mathrm{~min}$, and a final extension

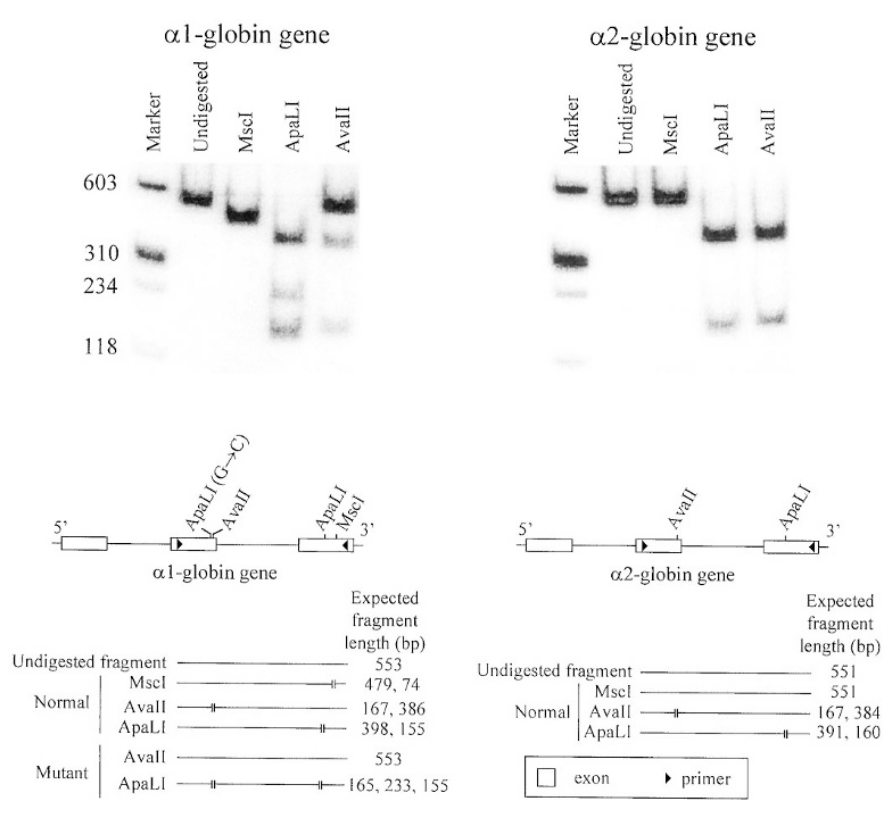

Figure 1. Identification of $94(\mathrm{G} \rightarrow \mathrm{C})$ mutation in $\alpha 1$-globin gene by PCR. The subject is heterozygous for $\alpha 1$-globin gene and homozygous normal for $\alpha 2$-globin gene. Markers are $\phi X 174 / H a e I I I$ digest. The location of the restriction sites and expected lengths of the DNA fragments are listed below the autoradiographs.
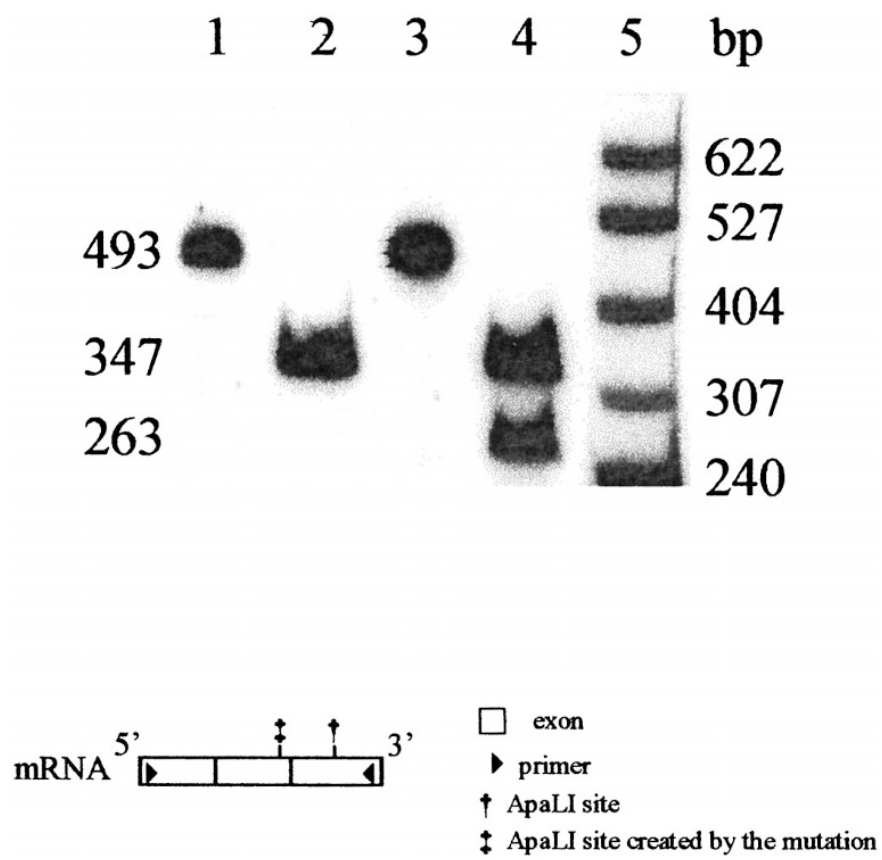

Figure 2. RT-PCR of $\alpha 2$-globin mRNA. Top, Lane 1 and 2 represent the undigested and ApaL I-digested product, respectively, for a normal subject; lanes 3 and 4, undigested and ApaL I-digested product, respectively, for a patient with an $\alpha 2$-globin mutation. Lane 5 contains pBR322DNA/MscI markers. Bottom, Location of the restriction enzyme sites and primers used in this study.

at $72^{\circ} \mathrm{C}$ for $10 \mathrm{~min}$ was done in a Perkin-Elmer thermal cycler. The amplified product was electrophoresed on $2 \%$ metaphor agarose. The band containing the PCR fragment was purified from the gel with the Qiaquick gel extraction kit (Qiagen). The $\alpha 1$ and $\alpha 2$ DNA fragments were sequenced using the Thermo 
Sequenase kit (Amersham Pharmacia Biotech) with the same upstream primer.

To assess the mutation location on $\alpha 1$ or $\alpha 2$ gene locus, we labeled the DNA fragments by use of the same PCR technique described above by adding $2 \mu \mathrm{ci}\left[\alpha^{32} \mathrm{P}\right] \mathrm{dCTP}(3000 \mathrm{Ci} / \mathrm{mmol})$ (Amersham) to the reaction mix. Because the mutation abolishes the normal AvaII site at codon 94 and created a new ApaL I site, we used the respective restriction enzymes to evaluate whether the mutation was present in both $\alpha$ locus and both alleles. The specificity of $\alpha 2$ and $\alpha 1$ amplification was confirmed using Msc I restriction enzyme (BalI isoschizomer), which recognized a site in $\alpha 1$ and not in $\alpha 2$. Ten microliters of PCR product was digested separately with $10 \mathrm{U}$ of AvaII (Amersham Pharmacia Biotech), $10 \mathrm{U}$ of ApaL I (New England Biolabs), and $10 \mathrm{U}$ of Msc I (New England Biolabs) for $2 \mathrm{~h}$ at $37^{\circ} \mathrm{C}$. Fragments were resolved on $5 \%$ polyacrylamide gel and visualized on PhosporImager (Molecular Dynamics).

$\boldsymbol{R} \boldsymbol{N} \boldsymbol{A}$ Analysis. Total RNA was isolated using RNeasy blood kit (Qiagen). To determine the ratio of mRNA $\alpha 2 / \alpha 1$, we used RNase protection assay as previously published (9). To quantify the relative amounts of normal and mutant mRNA, we used RT-PCR based on published methods (10). At first, 0.5 $\mu \mathrm{g}$ of RNA was reverse transcribed using $0.5 \mu \mathrm{g}$ of oligo dT primer (GIBCO) in 1X PCR buffer (GIBCO), $0.2 \mathrm{mM}$ dNTP, $1.5 \mathrm{mM} \mathrm{MgCl}_{2}, 10 \mathrm{mM}$ DTT, $40 \mathrm{U}$ of RNA guard (Amersham Pharmacia Biotech), with $400 \mathrm{U}$ of M-MLV reverse transcriptase (GIBCO) by incubation at $42^{\circ} \mathrm{C}$ for $60 \mathrm{~min}$ followed by inactivation of reverse transcriptase at $94^{\circ} \mathrm{C}$ for $5 \mathrm{~min}$. The entire reverse-transcribed sample was then PCR amplified in a $50-\mu \mathrm{L}$ volume containing 25 pmol of common upstream primer-5'CGACAAGACCAACGTCAAGG3' (located in Fig. 2), 25 pmol of the desired $\alpha$-specific downstream primer (described above), and $1.25 \mathrm{U}$ of Taq polymerase (GIBCO). Cycling was $94^{\circ} \mathrm{C}$ for $1 \mathrm{~min}, 52^{\circ} \mathrm{C}$ for $1 \mathrm{~min}, 72^{\circ} \mathrm{C}$ for $1 \mathrm{~min}$, for 30 cycles and a final extension at $72^{\circ} \mathrm{C}$ for $10 \mathrm{~min}$ done in a Perkin-Elmer thermal cycler. The upstream primer $(800$ pmol) was labeled to high specific activity with $5 \mu \mathrm{L}$ of $\gamma^{32}$ P-ATP (6000ci/mmol) (Amersham), $30 \mathrm{U}$ of polynucleotide kinase (New England Biolabs), and purified on a Qiaquick nucleotide removal kit (Qiagen). Ten microliters of the amplified products was then radioactively labeled with ${ }^{32} \mathrm{P}$ end-labeled upstream primer by one cycle of extension. The reaction mixture contained $1 \mathrm{X}$ PCR buffer (GIBCO), $0.1 \mathrm{mM}$ dNTP, $1.5 \mathrm{mM} \mathrm{MgCl}$, $40 \mathrm{pmol}$ of labeled primer, and $1.25 \mathrm{U}$ of Taq polymerase (GIBCO) in final volume of $20 \mu \mathrm{L}$ (denaturation for $3 \mathrm{~min}$ at $94^{\circ} \mathrm{C}$, annealing for $2 \mathrm{~min}$ at $52^{\circ} \mathrm{C}$, and extension for $10 \mathrm{~min}$ at $72^{\circ} \mathrm{C}$ ). Ten microliters of the labeled PCR product was subsequently digested with $10 \mathrm{U}$ of ApaL I (New England Biolabs) for $2 \mathrm{~h}$ at $37^{\circ} \mathrm{C}$ and resolved on a nondenaturing $6 \%$ polyacrylamide gel and quantified with PhosphorImager (Molecular Dynamics).

Genotype analysis. The $\alpha$-globin gene arrangement was confirmed by PCR amplification of genomic DNA similarly as described by Molchanova et al. (3). Briefly, $0.5 \mu \mathrm{g}$ of DNA was amplified for 35 cycles with an upper and downstream primer common for both $\alpha 1$ and $\alpha 2$, followed by a $5^{\prime}$ end labeling of the amplified product in a one-cycle PCR. A digestion of the amplified product with the restriction enzyme ApaI, which has a site in $\alpha 1$-IVS-II, allowed the separation and quantitation of $\alpha 1$ and $\alpha 2$ DNA fragments.

The present study was approved by the Institutional Review Board and has been conducted with informed consent.

\section{RESULTS}

The $\mathrm{P}_{50}$ values for the carriers of the $\alpha 2$-globin mutant were $30.3 \pm 2.9 \mathrm{~mm} \mathrm{Hg}$ for the newborn infants and $32.5 \pm 2.6$ for the adults, whereas the mean $\mathrm{P}_{50}$ was $31.3 \pm 0.4$ for the adults with $\alpha 1$-globin mutant. The plasma erythropoietin and DPG concentrations both in adults and newborns were within normal limits (11-13). These results are shown in Table 1 .

An example of the globin chain separation from a newborn infant by HPLC after ${ }^{3} \mathrm{H}$-leucine labeling is shown in Figure 3. The split in the $\alpha$-globin peak identified the mutant $\alpha$-globin. Fetal $\mathrm{Hb}$ comprised $84 \%$ of the total $\mathrm{Hb}$, whereas synthesis of fetal $\mathrm{Hb}$ was $68 \%$ of total $\mathrm{Hb}$ synthesis. This level of $\mathrm{Hb} \mathrm{F}$ synthesis was within the normal range of term infants (14). The mutant $\alpha$-subunit was $28 \%$ of the total $\alpha$-subunits. As shown on Table 1, the mean $\alpha 1$ mutant globin of the infants included in this study was $23.8 \%$, whereas its synthesis was $26 \%$. Also, the mean $\alpha 2$ mutant globin level was $27 \%$ of total $\alpha$-globin, whereas its synthesis was $27 \%$ of total $\alpha$ synthesis.

Figure 4 illustrates the $\mathrm{Hb}$ ODC from a newborn with a low oxygen affinity hemoglobinopathy in comparison with the

Table 1. Hematologic and molecular analyses from subjects with mutations in either the $\alpha 2$ - or $\alpha 1$-globin gene

\begin{tabular}{|c|c|c|c|c|c|}
\hline & \multicolumn{2}{|c|}{ Mutation $\alpha 2$} & \multirow{2}{*}{ 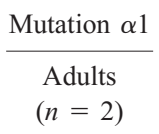 } & \multicolumn{2}{|c|}{ Normal } \\
\hline & $\begin{array}{c}\text { Newborns } \\
(n=7)\end{array}$ & $\begin{array}{l}\text { Adults } \\
(n=7)\end{array}$ & & Newborns & Adults \\
\hline $\mathrm{P}_{50}(\mathrm{~mm} \mathrm{Hg})$ & $30.3 \pm 2.9$ & $32.5 \pm 2.6$ & $31.3 \pm 0.4$ & $22 \pm 2^{(12)}$ & $27 \pm 1^{(13)}$ \\
\hline DPG $(\mu \mathrm{mol} / \mathrm{g} \mathrm{Hb})$ & $16.1 \pm 2.9$ & $16.0 \pm 2.6$ & $13.6 \pm 0.8$ & $14.8 \pm 2^{(12)}$ & $15 \pm 3^{(13)}$ \\
\hline Epo $(\mathrm{mU} / \mathrm{mL})$ & $7.4 \pm 2.9$ & $15.9 \pm 3.7$ & $13.9 \pm 2.3$ & $8 \pm 4^{(11)}$ & $15 \pm 5^{(11)}$ \\
\hline \multicolumn{3}{|c|}{$\alpha 2$-mutant globin synthesis/total $\alpha$-globin synthesis } & & \multicolumn{2}{|c|}{$27.5 \pm 2 \%$} \\
\hline \multicolumn{3}{|c|}{$\alpha 2$-mutant globin/total $\alpha$-globin total } & & \multicolumn{2}{|c|}{$27.3 \pm 1 \%$} \\
\hline \multicolumn{3}{|c|}{$\alpha 1$-mutant globin mRNA/total $\alpha 1$-globin mRNA } & & \multicolumn{2}{|c|}{$37.8 \pm 2 \%$} \\
\hline \multicolumn{3}{|c|}{$\alpha 1$-mutant globin synthesis/total $\alpha$-globin synthesis } & & \multicolumn{2}{|c|}{$26.1 \pm 1 \%$} \\
\hline \multicolumn{3}{|c|}{$\alpha 1$-mutant globin/total $\alpha$-globin total } & & \multicolumn{2}{|c|}{$23.8 \pm 1 \%$} \\
\hline
\end{tabular}




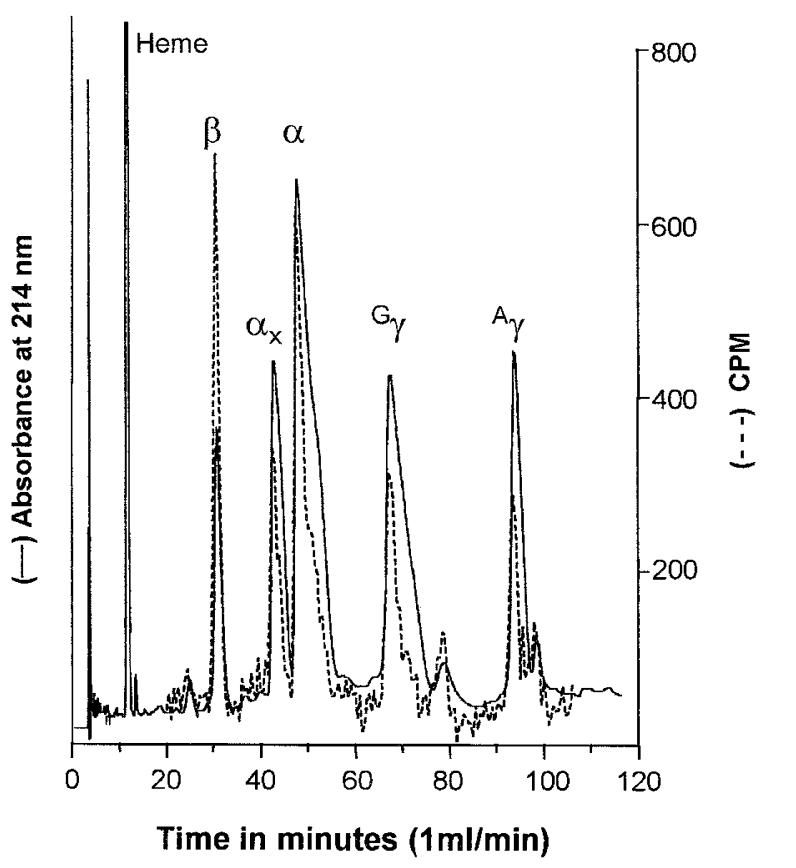

Figure 3. Relative amounts and rate of synthesis of the different globin chains determined by HPLC and ${ }^{3} \mathrm{H}$-leucine labeling from a newborn with an $\alpha$-globin mutation. $\alpha_{\mathrm{x}}$ denotes the mutant $\alpha$-globin.

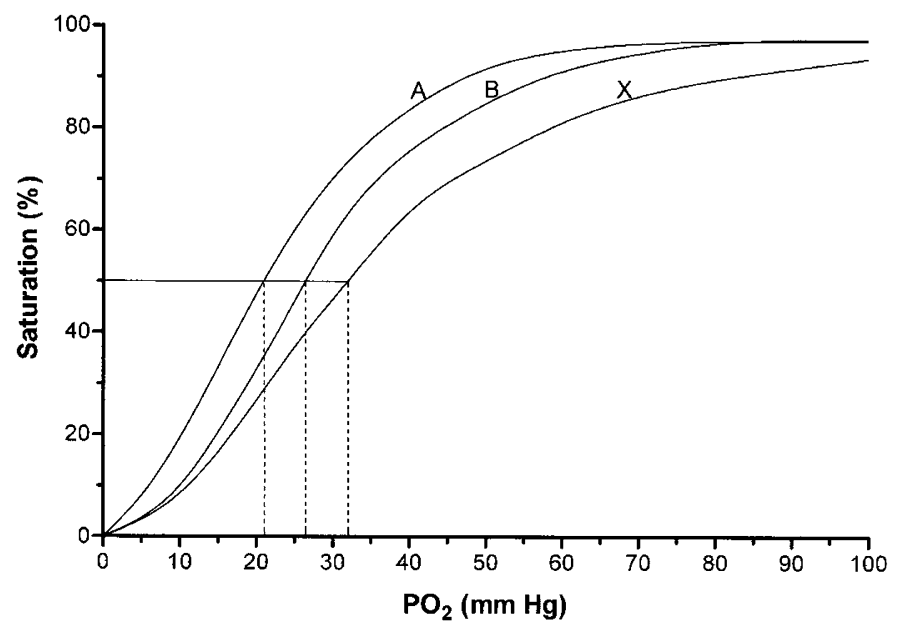

Figure 4. Hb oxygen affinity curves determined by Hemox-Analyzer. Normal term newborn blood $(A)$, normal maternal blood $(B)$, and newborn term infant blood with low-affinity hemoglobinopathy $(X)$.

normal mother as well as a normal control newborn infant. The normal maternal-fetal oxygen gradient is reversed because the mutation is on the $\alpha$-globin, and, therefore, it affects the $\mathrm{Hb}$ oxygen affinity during most of fetal development. Four of the infants included in this study were born to mothers without a hemoglobinopathy, which meant that these infants had a reversal of their maternal-fetal gradient during fetal life. There was no evidence of any adverse sequelae in these infants.

The results of the sequencing of the regions of the $\alpha$ genes in which the heterozygous mutations occurred are shown in Figure 5, which demonstrates the normal $\alpha 1$ and $\alpha 2$ gene as well as the $\alpha 1$ and $\alpha 2$ mutation in the region of interest. The mutation $\alpha 94 \mathrm{GAC} \rightarrow \mathrm{CAC}$ results in a replacement of asparagine by histidine. The confirmation of the presence of a

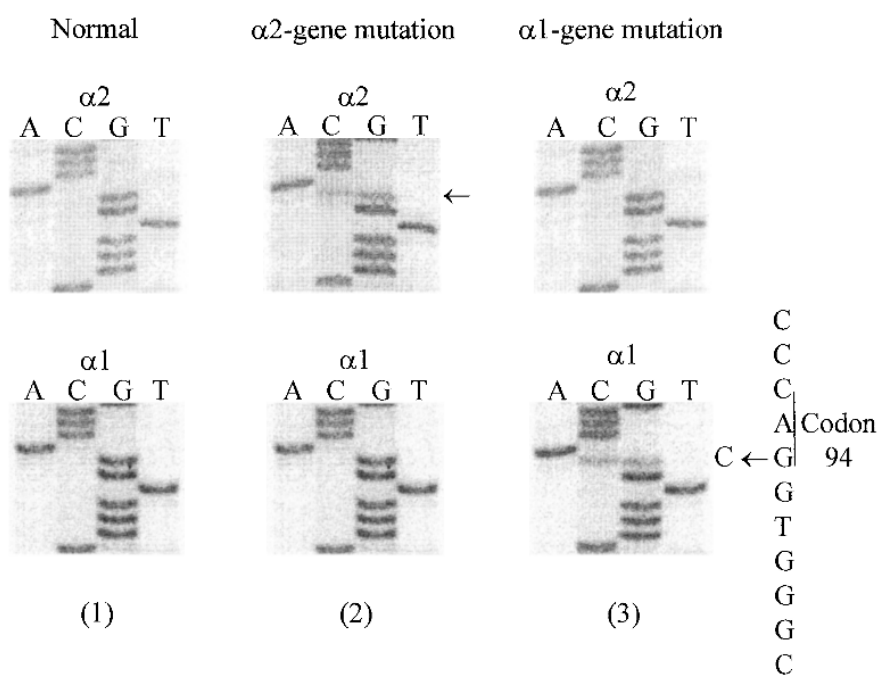

Figure 5. Identification of $94(\mathrm{G} \rightarrow \mathrm{C})$ mutation in $\alpha 1$ - and $\alpha 2$-globin genes by sequencing the PCR-amplified genomic DNA. (1) A normal subject, (2) a subject heterozygous for $94(\mathrm{G} \rightarrow \mathrm{C})$ in $\alpha 2$-globin gene, and (3) a subject heterozygous for $94(\mathrm{G} \rightarrow \mathrm{C})$ in $\alpha 1$-globin gene. The arrows point to the nucleotide change.

heterozygous $\alpha 1$ mutation is demonstrated in Figure 1. Figure 2 illustrates an example of the separation of the products of RT-PCR after ApaL I digestion, which provides the data to determine $\alpha 2$ mutant mRNA ratio to total $\alpha 2$ mRNA. The ratio of the sample shown in Figure 2 was $44.0 \%$. The mean percentages of $\alpha 2$ mutant mRNA in total $\alpha 2$ mRNA and $\alpha 1$ mutant in total $\alpha 1$ mRNA were $45.0 \pm 1.3 \%$ and $37.8 \pm 2 \%$, respectively. The ratio of the $\alpha 2$ - to $\alpha 1$-globin mRNA as determined by RNase protection assay ranged from 2.2 to 2.8 . The mean values of the ratio were similar in the newborns and the adults (as shown in Table 1).

The variations in $\alpha 1$ and $\alpha 2$ mutant mRNA abundance could not be attributed to deviations from normal $\alpha \alpha / \alpha \alpha$ genotype, because simultaneous amplification and quantification of $\alpha 1$ and $\alpha 2$ gene fragments revealed a ratio of 1.2. Thus, the subjects had a normal genetic complement of $\alpha \alpha / \alpha \alpha$.

The molecular analysis demonstrated a rare heterozygous mutation $\left[\alpha 94\left(\mathrm{G}_{1}\right) \mathrm{Asp} \rightarrow \mathrm{His}\right]$ on the $\alpha 2$ gene for all of the infants and their related adults except for a 13-y-old and her father in whom the identical mutation was found on the $\alpha 1$ gene.

\section{DISCUSSION}

The transport of oxygen from mother to fetus is believed to be aided by their differences in oxygen affinity. The ODC of paired fetal-maternal samples from 16 species of mammals have been studied showing that fetal oxygen affinity exceeds that of the maternal, the only exception being the cat in which they are the same $(15,16)$. Although nearly all mammals show such a difference, the usual difference in oxygen affinity between adult and fetal $\mathrm{Hb}$ has never been shown to be necessary for a healthy fetal development. The infants in this study were all born at term, appropriate in weight for gestational age and without any evidence of hypoxic erythropoietic stress. They are all followed by a pediatrician and are considered to be 
growing and developing normally. There are numerous cases described in which maternal blood has a higher oxygen affinity without any detrimental effects on the fetus (17). This difference in oxygen affinity between fetal and adult blood per se may not be an essential requirement for the transfer of oxygen across the placenta.

In this study, a rare mutation [ $\alpha 94(\mathrm{G} 1) \mathrm{Asp} \rightarrow \mathrm{His}]$ in one of the $\alpha 2$ alleles in a group of related French Canadian families from the same region of the Province of Quebec, Canada, as well as an identical mutant in one of the $\alpha 1$ alleles of a father and daughter of the same ethnic group but unrelated has been studied. The identical mutant could be the result of a gene conversion between duplicated loci or an independent mutation. Normally, when $\mathrm{Hb} \mathrm{A}$ is oxygenated, $\beta 102$ Asn forms a hydrogen bond with $\alpha 94$ Asp. An amino acid substitution at this location that is critical to $\mathrm{Hb}$ function prevents the formation of the bond between $\alpha 94$ and $\beta 102$ that normally stabilizes oxyhemoglobin. This phenomenon explains the low oxygen affinity mutants such as $\mathrm{Hb}$ Kansas ( $\beta 102 \mathrm{Asn} \rightarrow \mathrm{Thr}$ ), $\mathrm{Hb}$ Beth Israel $(\beta 102 \mathrm{Asn} \rightarrow \mathrm{Ser})$, and $\mathrm{Hb}$ Titusville $(\alpha 94 \mathrm{Asp} \rightarrow \mathrm{Asn})$ (18). The same mechanism is a likely explanation of the low oxygen affinity in the groups of patients of this study with $\mathrm{Hb}$ Sunshine Seth ( $\alpha 94 \mathrm{Asp} \rightarrow \mathrm{His}$ ). The individuals described in this study have no apparent clinical or hematologic abnormalities. Unexplained cyanosis in association with normal arterial oxygen pressure should prompt investigation for an abnormal $\mathrm{Hb}$ mutant and may obviate the need for extensive diagnostic procedures.

Although the protein products of the $\alpha 2$ and $\alpha 1$ genes are identical, methods exploiting the sequence divergence in their noncoding regions have enabled the relative amounts of $\alpha 2$ and $\alpha 1$ mRNA to be determined. The synthesis of an $\alpha$-globin mutant in a heterozygous individual represents the expression of one of the four $\alpha$-globin genes. The mean percentage of the abnormal globin in the $\alpha 2$ mutation was $27.5 \pm 1 \%$ and the $\alpha 1$ mutation $23.8 \pm 1 \%$. These values correspond to a ratio of $\alpha 2$ mutant to $\alpha 1$ mutant of 1.1 to 1 at both the protein and protein synthesis level, whereas the mean ratio of $\alpha 2$ and $\alpha 1$ mRNA ranged from 2.3 to 2.5 . This finding supports the observations of Molchanova et al. (3) showing that mutations at the two $\alpha$-globin loci result in small differences on their effects on $\alpha$-globin synthesis, but does not concord with the work of Liebhaber et al. (4) who carried out in vitro translation studies showing higher output of $\alpha 2$-globin gene in both mRNA and protein.

This mutant caused a reversal of the maternal fetal oxygen affinity gradient with no detrimental effects on fetal growth and development. The presence of an identical mutation on either the $\alpha 1$ - or the $\alpha 2$-globin gene in different individuals provided a unique opportunity to substantiate whether there is the exis- tence of a major and minor $\alpha$-globin locus. The observed base change was confirmed by amplification, sequencing, and/or digestion with specific restriction enzymes in samples from subjects with either $\alpha 1$ or $\alpha 2$ mutant globin. The effect of each of the identical $\alpha$-globin mutants on the lowering $\mathrm{Hb}$ oxygen affinity was the same. The mutant $\alpha 1$ - and $\alpha 2$-globin chains comprised close to $25 \%$ of the $\alpha$-globin chains in the circulating red cells as well as the newly synthesized mutant $\alpha$-globins in the reticulocytes. (If $\alpha 2$-globin were expressed 2.5 times $\alpha 1$-globin, the proportion of mutant $\alpha 1$-globin chains would be in the $10 \%$ range.) There was, thus, a 2.5 higher transcription of $\alpha 2$-globin gene compared with the $\alpha 1$-globin gene and a 2.5 higher efficiency in the translation of the $\alpha 1$-globin gene. The result is an almost equal synthesis of $\alpha$-globin chains by either one of the two genes.

\section{REFERENCES}

1. Shroeder WA, Shelton JB, Shelton JR, Powars D 1979 Hemoglobin Sunshine Seth $\alpha_{2}$ (94(G1)Asp $\rightarrow$ His) $\beta_{2}$. Hemoglobin 3:145-159

2. Liebhaber SA, Wain Kan Y 1982 Different rates of mRNA translation balance the expression of the two human $\alpha$-globin loci. J Biol Chem 257:11852-11855

3. Molchanova TP, Pobedimskaya DD, Huisman THJ 1994 The differences in quantities of $\alpha 2$ - and $\alpha 1$-globin gene variant in heterozygotes. Br J Haematol 88:300-306

4. Liebhaber SA, Cash FE, Ballas SK 1986 Human $\alpha$-globin gene expression. The dominant role of the $\alpha 2$-locus in mRNA and protein synthesis. J Biol Chem 261:15327-15333

5. Guarnone R, Centenara E, Barosi G 1995 Performance characteristics of HemoxAnalyzer for assessment of the hemoglobin dissociation curve. Haematologica $80: 426-430$

6. Bard H, Widness JA, Ziegler EE, Gagnon C, Peri KG 1995 The proportions of ${ }^{\mathrm{G}} \gamma$ and ${ }^{\mathrm{A} \gamma}$-globins in the fetal hemoglobin synthesized in preterm and term infants. Pediatr Res 37:361-364

7. Georgieff MK, Landon MB, Hedlund B, Faasen AE, Mills MM, Hedlund BE, Faasen AF, Schmidt RL, Ophouen JJ, Widness JA 1990 Abnormal iron distribution in infants of diabetic mothers: spectrum and maternal antecedents. J Pediatr 117:455-461

8. Keitt AS 1971 Reduced nicotinamide adenine dinucleotide-linked analysis of 2,3diphosphoglyceric acid: spectrophotometric and fluorometric procedures. J Lab Clin Med 77:470-475

9. Peri K, Gagnon C, Bard H 1998 Quantitative correlation between globin mRNAs and synthesis of fetal and adult hemoglobins during hemoglobin switchover in the perinatal period. Pediatr Res 43:504-508

10. Dimovski AJ, Efremov DG, Gu L-H, Huisman THJ 1994 The relative levels of $\beta^{\mathrm{A}}$ and $\beta^{\mathrm{S}}$ mRNAs in $\mathrm{Hb} \mathrm{S}$ heterozygotes and in patients with $\mathrm{HbS}-\beta^{+}$-thalassaemia or HbS- $\beta^{+}$-HPFH combinations. Br J Haematol 87:353-356

11. Cotes PM, Spivak JL 1991 Erythropoietin in health and disease. In: Erslev AJ, Adamson JW, Eschbach JW, Winearls CG (eds) Erythropoietin. The Johns Hopkins University Press, Baltimore, pp 184-207

12. Bard H, Teasdale F 1979 Red cell oxygen affinity, hemoglobin type, 2,3diphosphoglycerate, and $\mathrm{pH}$ as a function of fetal development. Pediatrics 64:483487

13. Bureau MA, Shapcott D, Berthiaume Y, Monette J, Blouin D, Blanchard P, Begin R 1983 Maternal cigarette smoking and fetal oxygen transport: a study of P50, 2,3diphosphoglycerate, total hemoglobin, hematocrit, and total $\mathrm{F}$ hemoglobin in fetal blood. Pediatrics 72:22-26

14. Bard H 1975 The postnatal decline of hemoglobin F synthesis in normal full-term infants. J Clin Invest 55:395-398

15. Metcalfe J, Bartels H, Moll W 1967 Gas exchange in the pregnant uterus. Physiol Rey 47:782-838

16. Novy MJ, Parer JT 1969 Absence of high blood oxygen affinity in the fetal cat. Respir Physiol 6:144-150

17. Charache S, Catalano P, Burns S, Jones RT, Koler RD, Rutstein R, Williams RR 1985 Pregnancy in carriers of high-affinity hemoglobins. Blood 65:713-718

18. Bunn HF 1994 Sickle hemoglobin and other hemoglobin mutants. In: Stamatoyannopoulos G, Nienhuis AW, Majerus PW, Varmus H (eds) The Molecular Basis of Blood Diseases. WB Saunders, Philadelphia, pp 207-256 